\title{
The predictive value of weight gain and waist circumference for gestational diabetes mellitus
}

\section{Gestasyonel diabetes mellitus için kilo alımının ve bel çevresinin prediktif değeri}

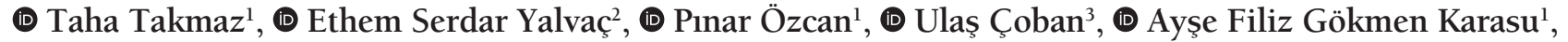 \\ (1) Mehmet Ünsal ${ }^{+}$ \\ 1 Bezmialem University Faculty of Medicine, Department of Obstetrics and Gynecology, İstanbul, Turkey \\ ${ }^{2}$ Bozok University Faculty of Medicine, Department of Obstetrics and Gynecology, Yozgat, Turkey \\ 3̇̀stanbul Şişli Hamidiye Etfal Training and Research Hospital, Clinic of Obstetrics and Gynecology, İstanbul, Turkey \\ ${ }^{4}$ Universitiy of Health Sciences, Elik Zübeyde Hanım Women's Diseases Training and Research Hospital, Clinic of Obstetrics and Gynecology, \\ Ankara, Turkey
}

\begin{abstract}
Objective: The first objective of this study was to investigate the relationship between gestational diabetes mellitus (GDM) and gestational weight gain (WG), waist circumference (WC), prepregnancy, and gestational body mass index (BMI). The second aim of our study was to assess the ability of WG, WC, prepregnancy, and gestational BMI with special reference to their cut-off points on predicting the risk of GDM in pregnant women in Turkey.

Materials and Methods: A total of 261 women who underwent screening for GDM with the 75-g glucose tolerance test (GTT) between $24^{\text {th }}$ and $28^{\text {th }}$ gestational weeks were included. According to the 75-g oral GTT results, women were classified into two groups: the GDM group and non-GDM group. The data collected included age, parity, plasma glucose level for fasting, 1- and 2-h tests, WC, prepregnancy and gestational BMI, prepregnancy weight, WG during pregnancy, gestational age at birth, and birth weight.

Results: WC at 20-24 weeks of gestation, prepregnancy BMI, and gestational BMI had a predictive capacity for GDM. According to our results, optimal cut-off points for the best predictive value of GDM were WC of $100 \mathrm{~cm}$ with a sensitivity of $84 \%$ and specificity of $70 \%$, prepregnancy BMI of $25 \mathrm{~kg} / \mathrm{m}^{2}$ with a sensitivity of $81.8 \%$ and specificity of $76 \%$, and gestational BMI of $28.3 \mathrm{~kg} / \mathrm{m}^{2}$ with a sensitivity of $75 \%$ and specificity of $77.4 \%$.

Conclusion: The measurement of prepregnancy BMI, gestational BMI, and WC may be useful in predicting the risk of GDM. Pregnant women with increased prepregnancy BMI, gestational BMI, and WC measurements may be susceptible to the development of GDM.

Keywords: Gestational diabetes mellitus, waist circumference, body mass index, weight gain, pregnancy

Öz

Amaç: Bu çalışmada birincil amaç gestasyonel diabetes melitus (GDM) gestasyonel kilo alımı (WG), karın çevresi (WC), pregestasyonel ve gestasyonel vücut kitle indeksi (VKI) ile olan ilişkisini araştırmak, ikincil amaç ise WG, WC, pregestasyonel ve gestasyonel VKI'nin Türkiye'deki hamile kadınlarda GDM riskini öngörebilmesi açısından sınır değerleri belirlemektir.

Gereç ve Yöntemler: Çalışmaya 24. ve 28. gebelik haftaları arasında 75 gr glukoz tolerans testi (GTT) ile GDM taraması yapılan toplam 261 kadın dahil edildi. Yetmiş beş g oral GTT sonuçlarına göre, kadınlar iki grup olarak sınılandırıldı: GDM grubu ve GDM olmayan grup. Yaş, parite, açlık plazma glukoz düzeyi, 1 . ve 2. saat plazma glukoz düzeyi, WC, pregestasyonel ve gestasyonel VKİ, pregestasyonel kilo, doğumdaki gebelik haftası ve bebeğin doğum ağırlığı kaydedildi.

Bulgular: Yirmi dördüncü. haftalardaki WC, pregestasyonel VKI ve gestasyonel VKI GDM’yi öngörebilmektedir. Elde ettiğimiz sonuçlara göre, GDM’yi predikte eden optimal değer WC için 100 (\%84 duyarlllı ve \%70 özgüllük), pregestasyonel VKİ $25 \mathrm{~kg} / \mathrm{m}^{2}$ (\%81,8 duyarlllı ve \%76 özgüllük) ve gestasyonel VKİ 28,3 kg/ $\mathrm{m}^{2}$ dir (\%75 duyarlılık ve \%77,4 özgüllük).

Sonuç: Pregestasyonel VKİ, gestasyonel VKİ ve WC ölçümü GDM riskini öngörmede faydalı olabilir. Artmış pregestasyonel VKİ, gestasyonel VKİ ve WC ölçümleri olan gebeler GDM gelişimi açısından risk grubundadır.

Anahtar Kelimeler: Gestasyonel diabetes mellitus, karın çevresi, vücut kitle indeksi, kilo alımı, gebelik
\end{abstract}

PRECIS: The objective of this study was to investigate the relationship between gestational diabetes mellitus and gestational weight gain, waist circumference, prepregnancy and gestational Body moss index in pregnant women in Turkey.

Address for Correspondence/Yazışma Adresi: Taha Takmaz, MD,

Bezmialem University Faculty of Medicine, Department of Obstetrics and Gynecology, İstanbul, Turkey

Phone: +90 5548707340 E-mail: thtkmz@hotmail.com ORCID ID: orcid.org/0000-0003-0793-2348

Received/Geliș Tarihi: 10.07.2019 Accepted/Kabul Tarihi: 15.09.2019

${ }^{\circledR}$ Copyright 2019 by Turkish Society of Obstetrics and Gynecology

Turkish Journal of Obstetrics and Gynecology published by Galenos Publishing House 


\section{Introduction}

Gestational diabetes mellitus (GDM) complicates 2-10\% of all pregnancies. It is defined as varying degrees of glucose intolerance first diagnosed during pregnancy ${ }^{(1,2)}$. The diagnosis and management of GDM is extremely important because of the strong relationship between GDM and increased maternal and neonatal risks ${ }^{(3,4)}$. However, maternal and fetal outcomes in pregnancies complicated by GDM are strongly related to metabolic control ${ }^{(5-7)}$. GDM is probably a combination of genetic predisposition, metabolic factors, environmental factors, and lifestyle such as dietary habits and physical activity. There are several predictive markers for GDM including maternal obesity, gestational weight gain (WG), waist circumference (WC), and prepregnancy and gestational body mass index $(\mathrm{BMI})^{(8,9)}$. Obesity is responsible for the central role in the pathogenesis of DM, a metabolic syndrome. WC and BMI seem to be more strongly linked to obesity. Increased BMI, a measure of general obesity, is a well-established risk factor for GDM. Increased WC, a simple and valid index of abdominal obesity, is an independent predictor for diabetes ${ }^{(3)}$. Maternal obesity is considered as an important predictive and modifiable marker in the short term for both maternal and fetal complications, including miscarriages, GDM, pregnancy-induced hypertensive disorders, macrosomia, maternal and fetal mortality, and cesarean sections, and in long-term risk factors for obesity and the metabolic syndrome in the child ${ }^{(10-14)}$. Moreover, maternal obesity, a major public health problem, has recently become more prevalent in line with the increase in the global prevalence of obesity. Maternal lifestyle is important for the reduction of GDM risk and the improvement of the total well-being of pregnant women and adverse pregnancy-related outcomes because pregnant women complicated with GDM have a higher prepregnancy and gestational BMI, a higher gestational WG, and a higher WC in general ${ }^{(15,16)}$. Thus, it should be an intervention focus. Turkish women may genotypically differ from other races and have different diet and lifestyle habits, which make them more vulnerable to obesity and GDM. However, body fat distribution is influenced by ethnicity. The first objective of this study was to investigate the relationship between GDM and gestational WG, WC, and prepregnancy and gestational BMI. The second aim of our study was to assess the ability of gestational WG, WC, and prepregnancy and gestational BMI, with special reference to their cut-off points, to predict the risk of GDM in pregnant women in Turkey.

\section{Material and Methods}

\section{Study design and study population}

The prospective cohort study was conducted at Department of Obstetrics and Gynecology of Etlik Zubeyde Hanim Women's Health Teaching and Research Hospital between March 2015 and June 2015. The study protocol was approved by the institutional local ethics committee and institutional education and planning committee. It was based on the analysis of the results of 261 pregnant women who attended our outpatient department. A total of 261 women who underwent screening for GDM with the 75-g glucose tolerance test (2-h GTT) between the $24^{\text {th }}$ and $28^{\text {th }}$ gestational weeks as recommended by International Association of Diabetes and Pregnancy Study Groups (IADPSG) were included ${ }^{(17)}$. An abnormal GTT was defined as a single abnormal value that established the diagnosis (abnormal values defined by IADPSG: fasting $\geq 92$, $1 \mathrm{~h} \geq 180$, and $2 \mathrm{~h} \geq 153 \mathrm{mg} / \mathrm{dL}$ ). According to the $75-\mathrm{g}$ oral GTT (OGTT) results, women were classified into two groups: the GDM group (abnormal response, confirmed disease) and the non-GDM group (normal response, disease free). The inclusion criteria consisted of age 18-41 years with a single pregnancy. Exclusion criteria were maternal diabetes mellitus diagnosed before pregnancy, multiple gestations, preterm or postterm pregnancies, congenital malformation, the use of hyperglycemic agents (corticosteroids and thyroid hormones), a history of systemic medical conditions, a history of GDM or macrosomia, and pregnancy-induced hypertensive disorders. The data collected included age, parity, plasma glucose level for fasting, 1- and 2-h tests, WC, prepregnancy and gestational BMI, prepregnancy weight, WG during pregnancy, gestational age at birth, and birth weight.

\section{Measurements}

WC was measured in the standing position, at the end of a normal expiration by using an inelastic tape $(0.5 \mathrm{~cm}$ x200 $\mathrm{cm}$ ) placed at the midpoint between the lower margin of the last palpable rib and the top of the iliac crest at the time of screening of $\mathrm{GDM}^{(18,19)}$. Prepregnancy and gestational BMI [(weight/height $\left.{ }^{2}\left(\mathrm{~kg} / \mathrm{m}^{2}\right)\right]$ was calculated using the World Health Organization criteria as the most useful epidemiologic measure of obesity. Women were allocated into low weight (BMI <18.5 kg/m²), normal weight (BMI=18.5-24.9 kg/ $\mathrm{m}^{2}$ ), overweight $\left(\mathrm{BMI}=25-29.9 \mathrm{~kg} / \mathrm{m}^{2}\right)$ and obese $($ BMI $\geq 30$ $\left.\mathrm{kg} / \mathrm{m}^{2}\right)^{(20)}$. Prepregnancy BMI was estimated based on selfreported prepregnancy weight. When prepregnancy weight was unknown, the weight measurement taken at the first prenatal clinic visit was used. Gestational BMI was determined based on the weight measurement taken at enrollment at the time of screening of GDM. WG was defined as the weight at enrollment (gestational weight) minus prepregnancy weight. WG percentage (WG\%) was calculated as (gestational weightprepregnancy weight/gestational weight) $\times 100^{(10)}$.

\section{Statistical Analysis}

Statistical analyses were performed using the Statistical Package for the Social Sciences, version 22 software package. Data were reported as mean \pm standard deviation or number and percentage. $\mathrm{P} \leq 0.05$ was considered significant. Normaly distributed continuous variables were assessed using independent Samples t-tests. Non-normally distributed metric variables were analysed using the Mann-Whitney U test. 
Spearman's correlation was used to evaluate the associations of GDM with the variables of interest (WC, prepegnancy and gestational, BMI, WG). A multivariate logistic regression model was used to calculate the odds ratios (ORs) and 95\% confidence intervals (CIs) for the likelihood of the prediction of GDM for WC, and prepegnancy and gestational BMI. Receiver operating characteristic (ROC) curves were constructed to calculate the sensitivity and specificity for different measures of prepegnancy and gestational BMI and WC in predicting GDM.

\section{Results}

Two hundred sixty-one women who underwent GDM screening with the 75-g OGTT were included in this study. The demographic and baseline obstetric characteristics of the women are shown in Table 1. There were 18 (6.9\%) women with low weight (BMI $\left.<18.5 \mathrm{~kg} / \mathrm{m}^{2}\right), 155$ (59.3\%) women with normal weight (BMI=18.5-24.9 kg/m²), 52 (19.9\%) women were overweight (BMI=25-29.9 kg/m²), and $36(13.7 \%)$ women were obese (BMI $\geq 30 \mathrm{~kg} / \mathrm{m}^{2}$ ). The mean ages of the women were $30.57 \pm 5.78$ years in the GDM group and $26.34 \pm 5.58$ years in the non-GDM group. Of the 261 women, 44 (16.85\%) who had abnormal 75-g OGTT were allocated to the GDM group. There were statistically significant differences in age, WC, fasting plasma glucose concentrations, 1- and 2-h tests, prepregnancy and gestational BMI, prepregnancy weight, WG during pregnancy, and gestational age at birth (weeks) between the GDM group and the non-GDM group (Table 1) ( $<<0.01$ ). In women with GDM, age, fasting plasma glucose concentration, 1and 2-h tests, prepregnancy and gestational BMI, prepregnancy weight, WG during pregnancy, and WC were significantly higher, and gestational age at birth was significantly lower compared with women in the non-GDM group (Table 1). The GDM and non-GDM groups were similar with regard to birth weight. Multivariate logistic regression analysis revealed that there was a positive correlation between GDM and WC, and prepregnancy and gestational BMI. WC $\geq 100 \mathrm{~cm}[\mathrm{OR}=8.36$; 95\% CI: (0.74-0.84); $<<0.01]$, prepregnancy BMI $\geq 25 \mathrm{~kg} / \mathrm{m}^{2}$ [OR=7.05; 95\% CI: (0.72-0.82); $\mathrm{p}<0.01]$, and gestational BMI $\geq 28.3 \mathrm{~kg} / \mathrm{m}^{2}$ [OR=7.2; 95\% CI: (0.73-0.83); $<<0.01$ ] increased the incidence of GDM (Table 2). ROC curve analysis showed that prepregnancy BMI $\geq 25 \mathrm{~kg} / \mathrm{m}^{2}$ predicted GDM with a sensitivity of $81.8 \%$ and specificity of $76 \%$ ( $A U C=0.78$ ); gestational BMI $\geq 28.3 \mathrm{~kg} / \mathrm{m}^{2}$ predicted GDM with sensitivity of $75 \%$ and specificity of $77.4 \%$ (AUC $=0.78$ ); and WC measurements $\geq 100$ $\mathrm{cm}$ predicted GDM with a sensitivity of $84 \%$ and specificity of 70\% (AUC=0.79) (Figure 1).

\section{Discussion}

The results of our study demonstrated that the prevalence of GDM in our study population was $16.8 \%$, and WC, prepregnancy, and gestational BMI, prepregnancy weight, and WG during pregnancy were significantly higher in women with
GDM. Therefore, these markers may independently predict the risk of developing GDM. Moreover, there was a positive correlation between GDM and WC, and prepregnancy and gestational BMI; finally, our results may suggest new cut-off points for WC $(\geq 100 \mathrm{~cm})$, prepregnancy BMI $\left(\geq 25 \mathrm{~kg} / \mathrm{m}^{2}\right)$ and gestational BMI $\left(\geq 28.3 \mathrm{~kg} / \mathrm{m}^{2}\right)$ for the prediction of GDM.

GDM is undoubtedly associated with increased adverse maternal and neonatal outcomes ${ }^{(21,22)}$. The diagnosis and treatment of GDM absolutely results in decreased risks of maternal and neonatal adverse effects related to $\mathrm{GDM}^{(23)}$. Screening is important for the diagnosis of GDM because affected women are often asymptomatic. The screening of GDM may consist of either a one or a two-step approach. The IADPSG promoted the one-step approach (75 g, 2-h GTT at 24-28 weeks' gestation) for the screening of GDM primarily based on the hyperglycemia and adverse pregnancy outcome trial data conducted to evaluate the association between mild hyperglycemia and adverse pregnancy outcomes in $2010^{(24)}$. The one-step approach was subsequently adopted by the American Diabetes Association in 2011 (25). We also adopted the one-step approach for the screening of GDM because of the cost-effectiveness and ease of application, and a relatively inexpensive future type 2 DM follow-up of the one-step approach. A retrospective study from Turkey demonstrated the prevalence of GDM as $4.8 \%, 8 \%$, and $13.4 \%$ using the National Diabetes Data Group, Carpenter-Coustan and O'Sullivan two-step approach, respectively, and 22.3\% with the IADPSG single-step approach. The study also reported that the prevalence of GDM increased with increasing age ${ }^{(26)}$. The pre-pregnancy or antenatally prediction of the risk of GDM with different strategies allows to reduce the incidence of GDM and improve maternal and infant health through the prevention of GDM (dietary, physical activity, behavior modification) or accurate diagnosis and appropriate treatment ${ }^{(27,28)}$. Overweight or obese, maternal age older than 35 years, excessive gestational WG, chronic hypertension, a history of GDM, strong family history of diabetes, polycystic ovarian syndrome, macrosomia, and stillbirth in a previous pregnancy, and high-risk racial/ ethnic group are well-known risk factors for $\operatorname{GDM}^{(29,30)}$.
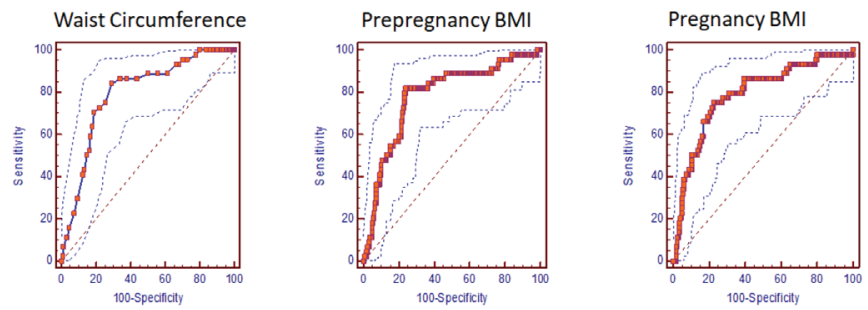

Figure 1. Receiver operating characteristic curve-sensitivity and specificity of waist circumference at 20-24 gestational weeks of pregnancy, prepregnancy and gestational body mass index to predict gestational diabetes mellitus

BMI: Body mass index 
Table 1. Demographic and baseline obstetric characteristics of groups

\begin{tabular}{|c|c|c|c|}
\hline Variables & GDM group $(n=44)$ & Non-GDM group $(n=217)$ & $P$ value \\
\hline Age & $30.57 \pm 5.78(18-40)$ & $26.34 \pm 5.58(18-39)$ & $<0.01^{*}$ \\
\hline Parity & $1.14 \pm 1.11(0-4)$ & $0.94 \pm 0.94(0-4)$ & 0.21 \\
\hline $1 \mathrm{~h}$ test & $177.82 \pm 38.00(100-252)$ & $115.65 \pm 23.52(55-180)$ & $<0.01^{*}$ \\
\hline $2 \mathrm{~h}$ test & $145.86 \pm 29.58(77-207)$ & $98.53 \pm 20.75(46-148)$ & $<0.01^{*}$ \\
\hline Waist circumference & $103.91 \pm 14.13(63-122)$ & $96.07 \pm 10.64(56-120)$ & $<0.01^{*}$ \\
\hline Weight gain during pregnancy & $10.71 \pm 5.94(0-32.39)$ & $7.92 \pm 4.28(0-16.07)$ & $<0.01^{*}$ \\
\hline Gestational age at birth (weeks) & $38.18 \pm 0.97(37-40)$ & $38.66 \pm 1.16(37-41)$ & $<0.01^{*}$ \\
\hline Birth weight (g) & $3287.50 \pm 565.80(2280-4500)$ & $3229.56 \pm 420.93(2180-4400)$ & $<0.01^{*}$ \\
\hline Prepregnancy weight (kg) & $72 \pm 14.63(47-98)$ & $60.52 \pm 12.76(42-120)$ & $<0.01^{*}$ \\
\hline
\end{tabular}

Table 2. Multivariable analysis to predict to the presence of gestational diabetes mellitus

$\begin{array}{lllll}\text { Variables } & \text { OR } & \text { P value } & 95 \% \mathrm{CI} \\ \text { WC } & 8.36 & <0.01^{*} & 0.74-0.84 \\ \text { Prepregnancy BMI } & 7.05 & <0.01^{*} & 0.72-0.82 \\ \text { Gestational BMI } & 7.2 & <0.01 * & 0.73-0.83\end{array}$

Waist circumference $<100$ vs. $\geq 100 \mathrm{~cm}$, prepregnancy body mass index $<25$ vs. $\geq 25$ $\mathrm{kg} / \mathrm{m}^{2}$ and gestational body mass index $<28.3 \mathrm{vs} . \geq 28.3 \mathrm{~kg} / \mathrm{m}^{2}$, " $\mathrm{p}<0.05$, significant difference, BMI: Body mass index, CI: Confidence interval, OR: Odds ratio, WC: Waist circumference

Maternal obesity is potentially a well-established risk factor for GDM and it is associated with some adverse maternal and neonatal outcomes such as preeclampsia, GDM, preterm birth, large-for-gestational-age babies or macrosomia ${ }^{(31-33)}$. Maternal obesity is principally defined based on the basis of WC and pre-pregnancy BMI. BMI is the most widely used method to determine total body fat and WC is a more practical measure for abdominal fat mass. A recent systematic review indicated that the risk of GDM was positively correlated with prepregnancy BMI, and the prevalence of GDM increased by $0.92 \%$ with every $1 \mathrm{~kg} / \mathrm{m}^{2}$ increase in BMI [95\% CI: $\left.(0.73-1.10)\right]^{(8)}$. A populationbased study including 6795 women with GDM evaluated singleton pregnancies complicated by GDM in underweight and normal weight women. The authors reported 301 underweight women and 6494 women with normal BMI of 6795 women with GDM. According to their results, underweight women were younger, more often nulliparous, and had a lower incidence of birthweight $>4000 \mathrm{~g}^{(34)}$.

However, several studies demonstrated that excessive gestational WG and gestational BMI might increase the risk of $\mathrm{GDM}^{(35,36)}$. Studies that assess cut-off points for prepregnancy and gestational BMI and WC based on race/ethnicity to predict GDM really important because body fat distribution is influenced by race/ethnicity. Madhavan et al. ${ }^{(37)}$ clearly demonstrated that there was a strong correlation between maternal obesity and obstetric complications. This pilot study conducted on
Asian and Indian patients found that WC of $85.5 \mathrm{~cm}$ and a BMI of $24.3 \mathrm{~kg} / \mathrm{m}^{2}$ had the best predictive value for $\mathrm{GDM}^{(37)}$. A cross-sectional study that included 240 women from Brazil showed that prepregnancy BMI $(\mathrm{OR}=4.21)$, gestational BMI $(\mathrm{OR}=3.17)$, and $\mathrm{WC}$ at $20-24$ weeks $(\mathrm{OR}=4.02)$ were associated with developing GDM. According to the results of this study, WC at 20-24 weeks' gestation is an important risk factor for GDM, and the range of $86-88 \mathrm{~cm}$ of WC has the best predictive performance for $\mathrm{GDM}^{(38)}$. Our results suggested that WC at 2024 weeks' gestation, prepregnancy BMI, and gestational BMI had predictive capacity for GDM. According to our results, the optimal cut-off points for the best predictive value of GDM are WC of $100 \mathrm{~cm}$ with a sensitivity of $84 \%$ and specificity of $70.9 \%$, prepregnancy BMI of $25 \mathrm{~kg} / \mathrm{m}^{2}$ with a sensitivity of $81.8 \%$ and specificity of $76 \%$, and gestational BMI of $28.3 \mathrm{~kg} /$ $\mathrm{m}^{2}$ with a sensitivity of $75 \%$ and specificity of $77.4 \%$.

\section{Study Limitations}

The main strength of our study was its population-based and prospective nature with adjustment for the predictive capacity of traditional GDM risk factors and the selection of best predictive value of the cut-off points of prepregnancy and gestational BMI and WC for our country. The limitations of our study was the relatively small sample size.

\section{Conclusion}

Our results confirm that the measurement of prepregnancy BMI, gestational BMI, and WC may be useful in predicting the risk for GDM. Pregnant women with increased prepregnancy BMI, gestational BMI, and WC measurements may be susceptible to the development of GDM. The cut-off points of prepregnancy BMI $\geq 25 \mathrm{~kg} / \mathrm{m}^{2}$, gestational BMI $\geq 28.3 \mathrm{~kg} / \mathrm{m}^{2}$ for being generally overweight, and WC $\geq 100 \mathrm{~cm}$ for central obesity were associated with increased risks of GDM. Determining these threshold points for prepregnancy BMI, gestational BMI, and WC measurements may be helpful in defining risky pregnant women in early pregnancy. Further well-designed randomized 
controlled trials are required to evaluate the use of these simple indicators of obesity for predicting GDM in pregnant women before these values can be used in clinical practice.

\section{Ethics}

Ethics Committee Approval: This study was approved by the Research Ethics Committee of the Zübeyde Hanım Women's Health Training and Research Hospital Clinical Research Hospital (approval number: 196 23/06/2015).

Informed Consent: Written informed consent was obtained from all patients

Peer-review: Externally peer-reviewed.

\section{Authorship Contributions}

Surgical and Medical Practices: T.T., Concept: E.S.Y., T.T., Design: E.S.Y., Data Collection or Processing: T.T., M.Ü., Analysis or Interpretation: A.F.G.K., Literature Search: U.Ç., Writing: P.Ö.

Conflict of Interest: No conflict of interest was declared by the authors.

Financial Disclosure: The authors declared that this study received no financial support.

\section{References}

1. Hunt KJ, Schuller KL. The increasing prevalence of diabetes in pregnancy. Obstet Gynecol Clin North Am 2007;34:173-99, vii.

2. American Diabetes Association (ADA). Diagnosis and classification of diabetes mellitus. Diabetes Care 2009;32:62-7.

3. Schmidt MI, Duncan BB, Reichelt AJ, Branchtein L, Matos MC, Costa e Forti A, et al. Brazilian Gestational Diabetes Study group. Gestational diabetes mellitus diagnosed with a 2-h 75-g oral glucose tolerance test and adverse pregnancy outcomes. Diabetes Care 2001;24:1151-5.

4. Khandelwal M, Homko C, Reece EA. Gestational diabetes mellitus: controversies and current opinions. Curr Opin Obstet Gynecol 1999;11:157-65.

5. Casey BM, Lucas MJ, Mcintire DD, Leveno KJ. Pregnancy outcomes in women with gestational diabetes compared with the general obstetric population. Obstet Gynecol 1997;90:869-73.

6. de Veciana M, Major CA, Morgan MA, Asrat T, Toohey JS, Lien JM, et al. Postprandial versus preprandial blood glucose monitoring in women with gestational diabetes mellitus requiring insulin therapy. N Engl J Med 1995;333:1237-41.

7. Langer O, Rodriguez DA, Xenakis EM, McFarland MB, Berkus MD, Arrendondo F. Intensified versus conventional management of gestational diabetes. Am J Obstet Gynecol 1994;170:1036-46

8. Torloni MR, Betrán AP, Horta BL, Nakamura MU, Atallah AN, Moron AF, et al. Prepregnancy BMI and the risk of gestational diabetes: a systematic review of the literature with meta-analysis. Obes Rev 2009;10:194-203.

9. Qiao Q, Nyamdorj R. Is the association of type II diabetes with waist circumference or waist-to-hip ratio stronger than that with body mass index? Eur J Clin Nutr 2010;64:30-4.

10. Guelinckx I, Devlieger R, Beckers K, Vansant G. Maternal obesity: pregnancy complications, gestational weight gain and nutrition. Obes Rev 2008;9:140-50.

11. The National Academies Press. National Research Council, Institute of Medicine. Influence of pregnancy weight on maternal and child health. Workshop report. Committee on the Impact of Pregnancy Weight on Maternal and Child Health. Board on Children, Youth, and Families, Division of Behavioral and Social Sciences and Education and Food and Nutrition Board, Institute of Medicine. Washington, DC: The National Academies Press; 2007.

12. Boney CM, Verma A, Tucker R, Vohr BR. Metabolic syndrome in childhood: association with birth weight, maternal obesity, and gestational diabetes mellitus. Pediatrics 2005;115:e290-6.

13. Scifres C, Feghali M, Althouse AD, Caritis S, Catov J. Adverse Outcomes and Potential Targets for Intervention in Gestational Diabetes and Obesity. Obstet Gynecol 2015;126:316-25.

14. Ferraro ZM, Contador F, Tawfiq A, Adamo KB, Gaudet L. Gestational weight gain and medical outcomes of pregnancy. Obstet Med 2015;8:133-7.

15. Harizopoulou VC, Kritikos A, Papanikolaou Z, Saranti E, Vavilis D, Klonos E, et al. Maternal physical activity before and during early pregnancy as a risk factor for gestational diabetes mellitus. Acta Diabetol 2010;47:83-9.

16. Blum JW, Beaudoin CM, Caton-Lemos L. Physical activity patterns and maternal well-being in postpartum women. Matern Child Health J 2004:8:163-9.

17. International Association of Diabetes and Pregnancy Study Groups Consensus Panel, Metzger BE, Gabbe SG, Persson B, Buchanan $\mathrm{TA}$, Catalano PA, et al. International association of diabetes and pregnancy study groups recommendations on the diagnosis and classification of hyperglycemia in pregnancy. Diabetes Care 2010;33:676-82.

18. Wendland EM, Duncan BB, Mengue SS, Nucci LB, Schmidt MI. Waist circumference in the prediction of obesity-related adverse pregnancy outcomes. Cad Saude Publica 2007;23:391-8.

19. WHO STEPS. Section 3: guide to physical measurements (Step 2). Geneva. 2008. Disponivvel em:http://www.who.int/chp/steps/ Part3_Section3.pdf [Acessado em 28 June 2011.

20. WHO, 2000. The Asia-Pacific perspective: redefining obesity and its treatment. IASO International Association for the Study of Obesity, International Obesity Taskforce. World Health Organization, Regional Office for the Western Pacific, Manila, 2000.

21. Ferrara A, Weiss NS, Hedderson MM, Quesenberry CP Jr, Selby JV, Ergas IJ, et al. Pregnancy plasma glucose levels exceeding the American Diabetes Association thresholds, but below the National Diabetes Data Group thresholds for gestational diabetes mellitus, are related to the risk of neonatal macrosomia, hypoglycaemia and hyperbilirubinaemia. Diabetologia 2007;50:298-306.

22. Moses RG, Morris GJ, Petocz P, San Gil F, Garg D. The impact of potential new diagnostic criteria on the prevalence of gestational diabetes mellitus in Australia. Med J Aust 2011;194:338-40.

23. Landon MB, Spong CY, Thom E, Carpenter MW, Ramin SM, Casey $\mathrm{B}$, et al. A multicenter, randomized trial of treatment for mild gestational diabetes. N Engl J Med 2009;361:1339-48.

24. Metzger BE, Gabbe SG, Persson B, Buchanan TA, Catalano PA, Damm $P$ et al. International association of diabetes and pregnancy study groups recommendations on the diagnosis and classification of hyperglycemia in pregnancy. Diabetes Care 2010;33, 676-82.

25. Basevi V, Di Mario S, Morciano C, Nonino F, Magrini N. Comment on: American Diabetes Association. Standards of medical care in diabetes--2011. Diabetes Care 2011;34:e53

26. Akgöl E, Abuşoğlu S, Gün FD, Ünlü A. Prevalence of gestational diabetes mellitus according to the different criterias. Turk J Obstet Gynecol 2017;14:18-22.

27. Kennelly MA, McAuliffe FM. Prediction and prevention of 
Gestational Diabetes: an update of recent literature. Eur J Obstet Gynecol Reprod Biol 2016;202:92-8.

28. Aktün HL, Uyan D, Yorgunlar B, Acet M. Gestational diabetes mellitus screening and outcomes. J Turk Ger Gynecol Assoc 2015;16:25-9.

29. Garrison A. Screening, diagnosis, and management of gestational diabetes mellitus. Am Fam Physician 2015;91:460-7.

30. Solmaz Hasdemir P, Terzi H, Koyuncu FM. Recent advances in the diagnosis and management of gestational diabetes. Turk J Obstet Gynecol 2014;11:181-5.

31. Hod M. Hyperglycemia and adverse pregnancy outcome (HAPO) study: Preeclampsia. Pregnancy Hypertens 2011;1:246-7.

32. Spaight C, Gross J, Horsch A, Puder JJ. Gestational diabetes mellitus. Endocr Dev 2016;31:163-78.

33. Farrar D, Simmonds M, Bryant M, Sheldon TA, Tuffnell D, Golder $S$, et al. Hyperglycaemia and risk of adverse perinatal outcomes: systematic review and meta-analysis. BMJ 2016;354:i4694.

34. Košir Pogačnik R, Trojner-Bregar A, Lučovnik M, Verdenik I,
Blickstein I, Tul N. Gestational diabetes mellitus in underweight women. J Matern Fetal Neonatal Med 2019:1-3.

35. Herring SJ, Oken E, Rifas-Shiman SL, Rich-Edwards JW, Stuebe $\mathrm{AM}$, Kleinman KP, et al. Weight gain in pregnancy and risk of maternal hyperglycemia. Am J Obstet Gynecol 2009;201:61.e1-7.

36. Shirazian N, Emdadi R, Mahboubi M, Motevallian A, Fazel-Sarjuei Z, Sedighpour N, et al. Screening for gestational diabetes: usefulness of clinical risk factors. Arch Gynecol Obstet 2009;280:933-7.

37. Madhavan A, Beena Kumari R, Sanal MG.A pilot study on the usefulness of body mass index and waist hip ratio as a predictive tool for gestational diabetes in Asian Indians. Gynecol Endocrinol 2008;24:701-7.

38. Bolognani CV, de Sousa Moreira Reis LB, de Souza SS, Dias A, Rudge MV, de Mattos Paranhos Calderon I. Waist circumference in predicting gestational diabetes mellitus. J Matern Fetal Neonatal Med 2014;27:943-8. 